Xinru Li, Min Zhou, Yidong Mi, Haiyan Chen, Hailei Su, Yuan Wei, Fuhan Guo, Fanfan Wang. Genetic and functional diversity of soil bacteria and fungi from different microhabitats in a karst region in Southern China. Journal of Cave and Karst Studies, v. 83, no. 3, p. $120-132$. DOI:10.4311/2020MB0106

\title{
GENETIC AND FUNCTIONAL DIVERSITY OF SOIL BACTERIA AND FUNGI FROM DIFFERENT MICROHABITATS IN A KARST REGION IN SOUTHERN CHINA
}

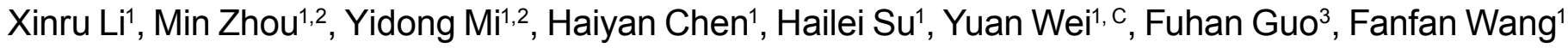

\begin{abstract}
Little is known about the difference between bacterial and fungal genetic and functional diversity in karst regions of south China. In this study, the genetic and functional diversity of bacteria and fungi in nine types of soil microenvironments in the karst region in Maolan National Nature Reserve in Guizhou were investigated by PCR-DGGE (Denaturing Gradient Gel Electrophoresis) and BIOLOG EcoPlates. Maolan National Nature Reserve is a UNESCO Biosphere Reserve and plays an important role in protecting the karst forest ecosystem and rare and endangered wild animals and plants in central Asia. The results showed that the diversity of both bacteria and fungi was high and the main factors influencing the diversity of bacteria and fungi were different. The bacterial community structure from different microhabitats under the same vegetation type had higher similarity than similar microhabitats in different vegetation types, which could indicate that the bacterial community structure was mainly controlled by vegetation. For fungi, similar microhabitat species under different vegetation types had higher similarities than different microhabitats species under the same vegetation type, which could indicate that the fungal community structure is mainly controlled by microhabitats. In addition, the metabolic patterns of similar microhabitats in different vegetation were different, while the metabolic patterns of different microhabitats in the same vegetation were not obviously different. In conclusion, the effect of vegetation types on soil microbial functional diversity was greater than that of microhabitats, and this difference was reflected by the different degrees of influence on soil microbial genetic diversity and community structure.
\end{abstract}

\section{INTRODUCTION}

The karst in southern China represents the most typical tropical-subtropical karst in the world (Yan et al., 2020; Zhou et al., 2020). It is a unique environmental unit in the subtropical climate zone, with a large elevation gradient and carbonate rock area, complex topography, and ecological fragility (Bai et al., 2013; Tian et al., 2016; Deng et al., 2020). Because of the natural conditions and human influence, the karst regions in China now have some special features including uncertain hydrological conditions, soil degradation, and low environmental recoverability (Zeng et al., 2018; Bai and Zhou, 2020; Wang et al., 2020). Rocky desertification may be the most typical environmental problem in the karst region in Guizhou Province in southeast China. Karst rocky desertification means that under the background of the fragile karst environment in the subtropical climate zone, unreasonable human social and economic activities have already caused serious soil erosion, large-scale exposure of bedrock, serious decline in land productivity, and soil degradation that is similar to desert landscapes (Zhan et al., 2013; Wang, 2020). Rocky desertification is a biogeochemical process that could be influenced by bacteria and fungi, and the effect is interactive (Wei et al., 2011; Hui et al., 2019).

Microorganisms are widely distributed in soil and can affect many kinds of soil biochemical reactions (Chen et al., 2019; Gregorutti and Caviglia, 2019). Soil microbial diversity is the basis and guarantee of the soil microorganism ecological function and plays an important role in maintaining soil quality and ecosystem stability and health. Soil microbial diversity can provide lots of information on soil and human influence, so it can also be used as a sensitive indicator of evaluating ecosystem stability and monitoring the change of soil quality. Therefore, the study of microorganisms in karst regions has attracted lots of attention. By studying the soil microbial diversity in mountains and grasslands in karst regions in Guizhou, it indicated that soil fertility, microbial biomass, and diversity were closely-related to each other (Jin et al., 2019). Another study chose arbuscular mycorrhizal fungi (AMF) as the research subject and found that microhabitats in karst regions in Guangxi Province could influence the richness of AMF by changing physical and chemical properties of soil and the vegetation types (Zhao et al., 2019). Some studies have shown that in karst regions, the microbial diversity can be affected by the vegetation and microhabitats (Dassen et al., 2017; Xue et al., 2017; Yang et al., 2018). However, previous studies ignored the discussion of genetic and functional diversity, especially on the comparison between the fungi and bacteria in microhabitats of karst regions. The role of soil microorganisms became more obvious when rocky desertification control and ecological restoration became more and more urgent. Thus, the characteristics of soil microorganisms from different kinds of microhabitats in karst region needs to be discussed due to the key role of soil microorganisms in soil succession, properties, and fertility. The microhabitat is a different small unit that can be

${ }^{1}$ State Key Laboratory of Environmental Criteria and Risk Assessment, Chinese Research Academy of Environmental Science, Beijing 100012, P.R. China

${ }^{2}$ College of Environment, Hehai University, Nanjing 210098, P.R. China

${ }^{3}$ Key Laboratory of Environmental Protection and Ecological Construction, Shenyang Agricultural University, Shenyang 110866 P.R. China

c Corresponding Author: rbq-wy@163.com 
clearly distinguished in external form. There are various types of microhabitats, including stone surfaces, stone pits, stone trenches, and soil surfaces, which make the distribution of exposed rocks and soil uneven (Du and Wang, 2010).

We studied the genetic diversity of soil bacteria and fungi in karst regions in Guizhou by PCR and denaturing gradient gel electrophoresis (DGGE). We analyzed the functional diversity of soil bacteria and fungi using average well color development (AWCD) using BIOLOG EcoPlates to show the main carbon sources of soil microorganisms by Principal Component Analysis (PCA). Few previous studies have investigated the genetic and functional diversity of bacteria and fungi from different microhabitats. The specific goals of this study were: (1) to understand the distribution and physiological features of soil microorganisms in karst soil more comprehensively; (2) to identify which factors were important in driving bacterial and fungal community distribution in karst; and (3) to identify the main factors influencing soil microbial communities.

\section{MATERIALS AND METHODS}

\section{Site Description and Sampling}

Maolan Biosphere Reserve ( $25^{\circ} 09^{\prime}$ to $25^{\circ} 20^{\prime} \mathrm{N} 107^{\circ} 52^{\prime}$ to $\left.108^{\circ} 05^{\prime} \mathrm{E}\right)$ is situated in Libo County, Guizhou Province in southeast China. In April 1996, Maolan was included in the UNESCO International Man and Biosphere Reserve Network (MAB) and became a world biosphere reserve (https://en.unesco.org/mab). The main protection objects of the biosphere reserve are the mid-subtropical karst forest ecosystem and rare and endangered wildlife. The total area of the reserve is 21,330 ha, of which the core area covers 5,150 ha. The elevation here is $630-1075 \mathrm{~m}$ above sea level. According to the record of the weather station in Libo (altitude: $423.9 \mathrm{~m}$ ), the average annual temperature and precipitation of the reserve is $18.6^{\circ} \mathrm{C}$ and $1760 \mathrm{~mm}$ respectively. The annual precipitation from April to October is $1162 \mathrm{~mm}$, accounting for $80 \%$ of the annual precipitation, is the annual rainy season (Zhou, 1987). The rocks in Maolan karst forest are mainly limestone and dolomite, with quartz sandstone and a small amount of shale in some places (Han et al., 2008). The region is famous for its virgin forest that is well-preserved on the karst landscape. The ecosystem types in Maolan include subtropical and temperate rainforests and agroecosystems (with rice, rape, sweet potato and medicinal plants). Every year there are about 60,000 visitors coming here because of its karst landscapes, streams, ponds, and waterfalls. There are vegetation succession communities with different degrees of degradation in this area, and the vegetation communities are relatively complete under each degree of degradation, which are conducive to the comparative study of different vegetation types in the same area.

According to the main feature of karst vegetation succession, three representative vegetation types were selected (secondary forest, shrubbery, and primeval forest) (Table 1). In each forest succession vegetation type, four kinds of microhabitats were studied, namely, soil surface, stone ditch, stone seam, and stone surface. The stone ditch has a wider opening and $U$-shape cross section. There are well-developed tree and shrub layers in the stone ditch with some herbs, ferns, and litters. The stone seam has a narrow opening and V-shaped cross section. There are more ferns, litters, and semi-decomposed organic matter in the stone seam. All the microhabitats were natural rather than man-made. In fact, only the samples of stone seam, stone ditch, and soil surface were collected during the sampling process, because the vegetation and soil of the stone surface microhabitat rarely met our experimental needs (Fig 1). The sample of a microhabitat was composed of three parallel samples of the same microhabitats. In our sampling sites, the rock type is mainly limestone.

Our research was conducted in August 2018. When sampling, we determine appropriate sample sizes according to the area of each microhabitat. We mixed samples of the same microhabitats from each forest site. We used disinfected shovels to remove the topsoil when sampling. The sample was sieved through a $2 \mathrm{~mm}$ sieve to ensure thorough mixing, and the samples were stored at $4{ }^{\circ} \mathrm{C}$ and $-20{ }^{\circ} \mathrm{C}$ for later use. The soil in the study area is dominated by rendzina, a humus-rich soil formed from parent limestone and dolomite that are almost pure carbonate rocks. Except for the rainy season, the soil is relatively dry. The soil here is rich in $\mathrm{Ca}^{2+}, \mathrm{Mg}^{2+}$, and $\mathrm{HCO}_{3}{ }^{-}$, with a pH of 7.5 to 8.0, an organic matter content of $75.5 \mathrm{~g} \mathrm{~kg}^{-1}$ to $380 \mathrm{~g} \mathrm{~kg}^{-1}$, and a total nitrogen content of $6.06 \mathrm{~g} \mathrm{~kg}^{-1}$.

\section{PCR-DGGE Analysis of Bacterial Diversity}

DGGE can distinguish the sequence differences of target fragments with the same or similar molecular weight, and can be used to detect single base changes and genetic diversity, as well as polymorphism of PCR amplified DNA fragments. The principle of DGGE technology to detect nucleic acid sequences is that the DNA fragments of different sequences are denatured at their respective denaturant concentrations and eventually stagnate at their denaturant gradient position. Comparing PCR-DGGE dyed bands can determine the number and diversity of microorganisms in the soil samples (Muyzer and Smalla, 1998; Ma et al., 2003). Compared with other research methods of microbial diversity, this technology has some advantages. For example, PCR-DGGE can detect the whole microbial community (Zheng et al., 2013; Ling et al., 2020). Compared to modern molecular biology techniques, PCR-DGGE can analyze other microorganisms that coexist in the environment. By combining PCR-DGGE with other molecular biology techniques, we can get a more comprehensive analysis of microbial diversity. 
Table 1. The Background information of three types of vegetation in Maolan reserve.

\begin{tabular}{|c|c|c|c|c|}
\hline $\begin{array}{l}\text { Vegetation } \\
\text { Types }\end{array}$ & Slope & $\begin{array}{c}\text { Bedrock Exposed Rate } \\
(\%)\end{array}$ & $\begin{array}{c}\text { Vegetation Coverage } \\
(\%)\end{array}$ & Vegetation Characteristics \\
\hline $\begin{array}{c}\text { Primeval } \\
\text { Forest }\end{array}$ & $30-40$ & $60-90$ & $90-100$ & $\begin{array}{l}\text { The hierarchical structure is relatively complete, and the } \\
\text { differentiation of plants between the tree layer, shrub } \\
\text { layer, and herb layer is clear. The coverage of the tree } \\
\text { layer is more than } 80 \% \text { and the height is } 10-20 \mathrm{~m} \text {; the } \\
\text { height of the shrub layer is } 3-8 \mathrm{~m} \text { and the coverage is } \\
5-10 \% \text {. } \\
\text { The dominant species are mainly round fruit incense, } \\
\text { calyx haitong, small fruit Runan, green sandalwood, light } \\
\text { leaf haitong, Rhizophora chinensis, ten major merits, } \\
\text { celestial fruit and so on. The surface layer is covered } \\
\text { with lichen and moss. In addition, understory is covered } \\
\text { with } 3-5 \mathrm{~cm} \text { litter layer. }\end{array}$ \\
\hline
\end{tabular}

$\begin{array}{ccc}\begin{array}{c}\text { Secondary } \\ \text { Forest }\end{array} & 30-40 \quad 50-80 & 90-100\end{array}$

The hierarchical structure of the stand is clearly differentiated. The tree layer and shrub layer are relatively developed. The tree layer is 5-12 $\mathrm{m}$ high, while the coverage rate is over $80 \%$. The shrub layer is $2-3 \mathrm{~m}$ high, while the coverage is about $10 \%$.

The dominant species mainly include Caragana yungui, Quercus glauca, Castanopsis fargesii, Pinus massoniana, Haitong, gerbera, etc. There are also a small number of vine thorns, ferns, lichens and other mosses. The thickness of the litter layer under the forest is $1-2 \mathrm{~cm}$.

\begin{tabular}{|c|c|c|}
\hline Shrubbery & $20-30$ & \\
\hline
\end{tabular}

The vertical structure of the stand is simple, with few trees. It is mainly dominated by shrub layers, with a height of $2.5-3 \mathrm{~m}$, a coverage rate of over $80 \%$, and a large degree of canopy closure.

The dominant species are: Nandina domestica, Huaxiang, Gerbera, tiger thorn,Libo hornbeam, multiveined Cyclobalanopsis glauca, rose hip etc. The litter cover under the forest is about $1-2 \mathrm{~cm}$.

The whole PCR-DGGE processes were divided into sample DNA extraction, gene amplification, separation, and strip recovery sequencing. Total Soil DNA was extracted using the Power Soil DNA Isolation Kit (MO BIO) Kit. All the

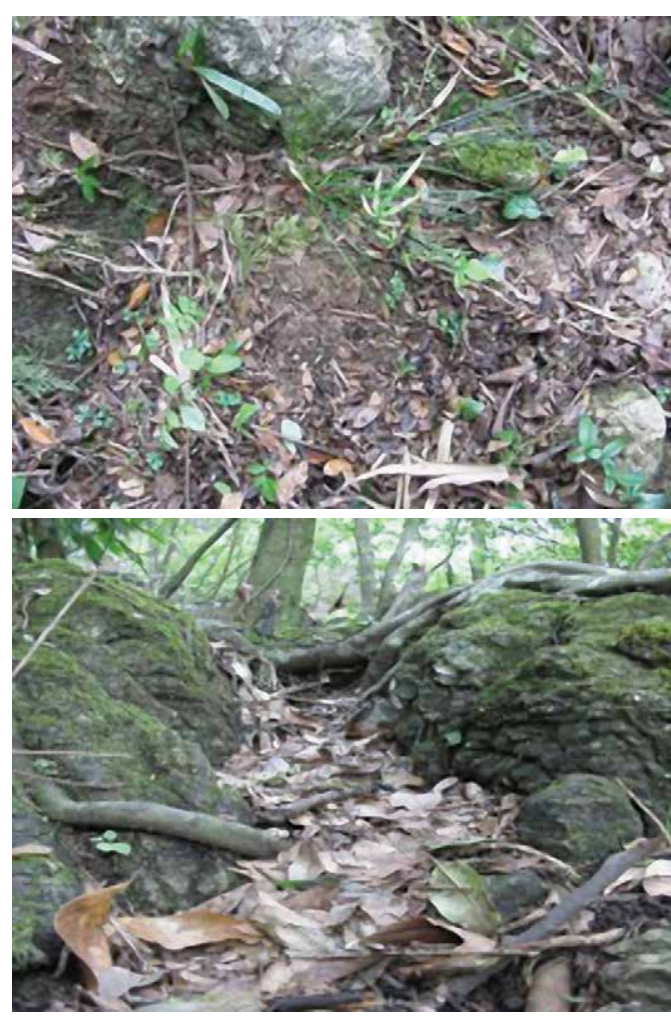
kit processes were strictly followed. For bacterial diversity analysis, the extracted DNA was used as templates for PCR. The amplification of bacterial DNA was performed using the universal $16 \mathrm{~S}$ rDNA primers F338GC (5'CGCCCGCCGCGCGCGGCGGGCGGGGCGGGGGCACGGGGGGCCTACGGAGGCAGCAG-3') and R518 (5'-ATTACCGCGGCTGCTGG-3') (Shanghai Shenggong Biological Engineering Technology Service Company). The pre-denaturation condition was $94{ }^{\circ} \mathrm{C}$ for 5 min using the Model 475 Gradient Delivery System (Bio-Rad Laboratories Company). The first 20 cycles

Figure 1. Different karst microhabitats in Maolan National Nature Reserve: A = Soil surface, B = Stone seam, and $\mathrm{C}=$ Stone ditch. were $94{ }^{\circ} \mathrm{C}$ for $1 \mathrm{~min}, 65-55$ ${ }^{\circ} \mathrm{C}$ for $1 \mathrm{~min}$, and $72{ }^{\circ} \mathrm{C}$ for 3 
$\min$ (the annealing temperature of each cycle decreased by $0.5^{\circ} \mathrm{C}$ ), and the last 10 cycles were $94{ }^{\circ} \mathrm{C}$ for $1 \mathrm{~min}, 55^{\circ} \mathrm{C}$ for $1 \mathrm{~min}$ and $72{ }^{\circ} \mathrm{C}$ for $3 \mathrm{~min}$, and finally, at $72{ }^{\circ} \mathrm{C}$ for $7 \mathrm{~min}$. After electrophoresis in $1.5 \%$ agarose gel, the products of the PCR reaction were stored at $-20^{\circ} \mathrm{C}$ degrees and analyzed by denaturing gradient gel electrophoresis. The denaturation gradient was from $30 \%$ to $60 \%$. The concentration of polyacrylamide gel was $8 \%$ in 1 XTAE. Electrophoresis was conducted at $200 \mathrm{~V}$ and $75 \mathrm{~V}$ for $10 \mathrm{~min}$ and $10 \mathrm{~h}$, respectively. After electrophoresis, the gel was dyed with silver dye (Bassam et al., 1991). The dyed gel was analyzed by BioRAD Gel doc-2000 Gel image analysis system, and all the electrophoresis bands were photographed.

\section{PCR-DGGE Analysis of Fungal Diversity}

The total DNA of soil samples was extracted and purified using the Mo BIO kit according to the manufacture's instruction, and the quality of extracted DNA was evaluated by $1 \%$ agarose gel electrophoresis. The product was stored at $-80^{\circ} \mathrm{C}$. The purified genomic DNA was used as a template for polymerase chain reaction (PCR). The PCR amplification was performed on the Mastercycler PCR machine. The primers of the fungi were U1: 5'-GTGAA ATTGTTGAAA GGGAA-3', U2-GC:5'-CGCCCGCCGCGCGCGGCGGGCGGGGCGGGGGCACGGGGGGGACTC CTTGGTCCGTGTT-3'. All the primers used in this study were provided by Shanghai ShengGong Bioengineering Technology Service Company. PCR reaction conditions of the fungi were as follows: the pre-denaturation conditions were $94^{\circ} \mathrm{C}$ for $3 \mathrm{~min}$, and then 35 cycles were performed at $94^{\circ} \mathrm{C}$ for $30 \mathrm{~s}, 53^{\circ} \mathrm{C}$ for $30 \mathrm{~s}, 72^{\circ} \mathrm{C}$ for 1 min and finally at $72{ }^{\circ} \mathrm{C}$ for $10 \mathrm{~min}$. All subsequent treatments were the same as for bacteria.

\section{Biolog Ecoplates Functional Diversity}

The fresh soil samples were weighed to $10 \mathrm{~g}$ of dry soil and placed in $100 \mathrm{~mL}$ sterile water, then oscillated for $20 \mathrm{~min}$ at $220 \mathrm{rpm}$. After dilution to $10^{-3}$ with sterile water, $125 \mu \mathrm{L}$ of diluted suspension was added to each well of Biolog ECO micropore plate (Biology, Hayward, CA, USA) using an 8-channel sample filler. After 168 hours of cultivation, Microlog Rel 4.2 software was used to read the absorbance value at $590 \mathrm{~nm}$ wavelength on the BIOLOG EmaxTM automatic plate reader (BIOLOG, Hayward, CA,USA) every 24 hours (Scuhutter and Dick, 2001). We have listed the carbon sources in Table 2.

\section{Statistical Analysis}

DGGE profiles were analyzed by Bio - Rad QUANTITY ONE 4.4.0 software. Comparisons of banding profiles were established by the dice coefficient $\left(C_{s}\right)$ that was drawn by the unweighted pair group method with arithmetic mean (UPGMA) plot

$$
C_{s}=\frac{2 j}{(a+b)},
$$

where $j$ is the band common to samples $A$ and $B$ and $a$ and $b$ are the respective number of bands in samples $A$ and $B$.

Shannon's index $(H)$, richness $(S)$, Simpson index $(D)$, Mcintosh index $(U)$ and evenness $(E)$ were used to characterize microbial diversity using the equations of Agryzkov et al., (2018). Average well color development (AWCD) could be used to access the microbial community's overall ability to exploit carbon sources.

Table 2. Correlation coefficients between main source of carbon and PC1 or PC2.

\begin{tabular}{|c|c|c|c|c|c|}
\hline $\begin{array}{c}\text { Carbon Source } \\
\text { Type (PC1) }\end{array}$ & Carbon Source & Load Value & $\begin{array}{c}\text { Carbon Source } \\
\text { Type (PC2) }\end{array}$ & Carbon Source & Load Value \\
\hline Carbohydrate & D-galactonic acid- $\gamma$-lactone & 0.750 & Carbohydrate & $\beta$-methyl-D-glucoside & 0.614 \\
\hline Amino acids & L-Arginine & 0.719 & Sugar & D-galactonic acid $\gamma$-lactone & 0.553 \\
\hline Carboxylic acids & D-galacturonic acid & 0.454 & Amino acids & L-Arginine & 0.383 \\
\hline Amino acids & L-asparagine & 0.448 & Polymer & Tween 40 & 0.404 \\
\hline Polymer & Tween 40 & 0.566 & Sugar & $\mathrm{N}$-acetyl-D glucosamine & 0.648 \\
\hline Carbohydrate & i-erythritol & 0.435 & Sugar & D-cellobiose & 0.443 \\
\hline Amino acids & L-phenylalanine & 0.776 & Sugar & $\alpha$-D-lactose & 0.476 \\
\hline Polymer & Tween 80 & 0.649 & Sugar & $D, L-\alpha$-glycerol phosphate & 0.626 \\
\hline Carbohydrate & D-mannitol & 0.523 & Carboxylic acids & D-malic acid & 0.502 \\
\hline Parent compound & 4-hydroxybenzoic acid & 0.596 & $\ldots$ & $\ldots$ & $\cdots$ \\
\hline Amino acids & L-serine & 0.598 & $\cdots$ & $\cdots$ & $\cdots$ \\
\hline Polymer & Glycogen & 0.441 & $\cdots$ & $\cdots$ & $\cdots$ \\
\hline Carboxylic acid & D-glucosamine & 0.490 & $\ldots$ & $\cdots$ & $\cdots$ \\
\hline Amino acids & Glycyl-L-glutamic acid & 0.698 & $\ldots$ & $\cdots$ & $\cdots$ \\
\hline Amine & phenethylamine & 0.507 & $\cdots$ & $\cdots$ & $\cdots$ \\
\hline Sugar & $\alpha$-D-lactose & 0.441 & $\cdots$ & $\cdots$ & $\cdots$ \\
\hline Amine & Putrescine & 0.688 & $\ldots$ & $\ldots$ & $\cdots$ \\
\hline
\end{tabular}




$$
A W C D=\frac{\Sigma(C-R)}{n},
$$

where $C$ is the optical density value of each well with culture medium, $R$ is the optical density value of the control well, $n$ is the data of the culture medium, and the $n$ value of the ECO plate is 31 (Guo et al., 2015; Miao et al., 2019).

Analysis of Variance (ANOVA) was performed on microorganisms and carbon sources uptake data using SPSS 16. The correlation matrix method is used to compress the data to obtain the different principal components and the distance between samples. The principal component values obtained after PCA analysis were used to analyze the differences between the inspection groups and correlate with environmental factors.

\section{RESULTS}

\section{Genetic Diversity Characteristics of Bacteria in Karst Microhabitats}

The bacterial communities of different soil samples were observed by DGGE (Fig. 2A). All nine lanes had a large number of bands, which show that each microhabitat was rich in bacterial diversity (Fig. 2B). At the same time, every lane had specific bands, which could illustrate that the diversity of bacteria among different microhabitats was quite different. From the DGGE profile, the shrubbery forest (lane 4, 5, and 6: line 34, 38, and 37 bands out of 78, respectively)

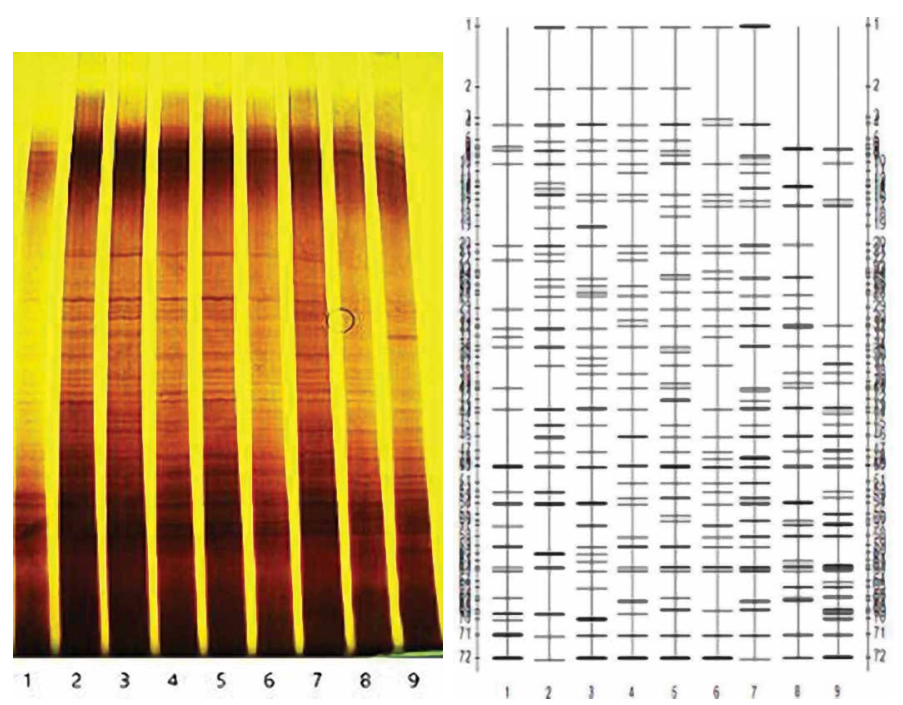

Figure 2. DGGE results of bacterial communities in different karst microhabitats samples: $A$ = DGGE profile of amplified of bacterial communities in different karst microhabitats samples, and $\mathrm{B}=$ DGGE sketch map of bacterial communities in different karst microhabitats samples. Numbering is: 1. Primeval forest surface; 2. Primeval forest stone ditch; 3. Primeval forest stone seam; 4. Shrubbery soil surface; 5 . Shrubbery stone ditch; 6 . Shrubbery stone seam; 7 . Secondary soil surface; 8 . Secondary forest stone ditch; and 9. Secondary forest stone seam. exhibited the most abundant bands, while the abundance of secondary and primeval forest were similar. Lane 1 from the shrubbery forest had the lowest number of bands; 24 bands out of 72 . The secondary forest stone ditch (lane 8 ) and the secondary forest stone seam (lane 9) had relatively fewer bands ( 28 and 30 bands out of 72 , respectively). The bacterial abundance from the soil surface, stone ditch, and stone seam may be very similar.

\section{Similarity Analysis of Bacterial Communities in Dif- ferent Karst Microhabitats}

Based on the similarity of bacterial communities in different microhabitat samples, cluster analysis results were shown by a dendrogram, along with the similarity index between lanes (Fig. 3, Table 3). The dendrogram gave rise to two main branches of clusters and shared a similarity of 0.39 . One branch cluster contains the secondary forest stone seam, soil surface and stone ditch, with the similarity of 0.47 . The bacterial communities between primary forest soil surface and stone seam stayed closer with a similarity of 0.51 . From the similarity index, the primary forest soil surface 1 had related with the primary forest stone ditch 2 (20.2\%) and the primary forest stone seam 3 (29.4\%). The shrubbery forest soil surface 4 had high correlation with the shrubbery forest stone ditch 5 (51.3\%) and the shrubbery forest stone seam 6 (44.6\%), which could illustrate that the similarity among different microhabitats of the same vegetation may be higher.

\section{Diversity and Richness Analysis}

We then calculated the diversity index of soil bacterial communities in different karst microhabitats samples, by Shannon index $(H)$, richness $(S)$ and evenness (E) (Table 4). The Shannon index and richness of shrubbery soil stone ditch were highest among all microhabitats, which were 3.65 and 39, respectively. The Shannon index and richness of primeval forest surface were only 3.13 and 24 , which were the lowest. The mean value of bacterial Shannon index among different microhabitats was 3.46. In terms of evenness index, except for the primeval forest surface and secondary forest stone ditch, which were slightly lower, the others remained at 1.00. The trends of bacterial Shannon index and the richness of primeval forest microhabitats were: stone seam $>$ stone ditch $>$

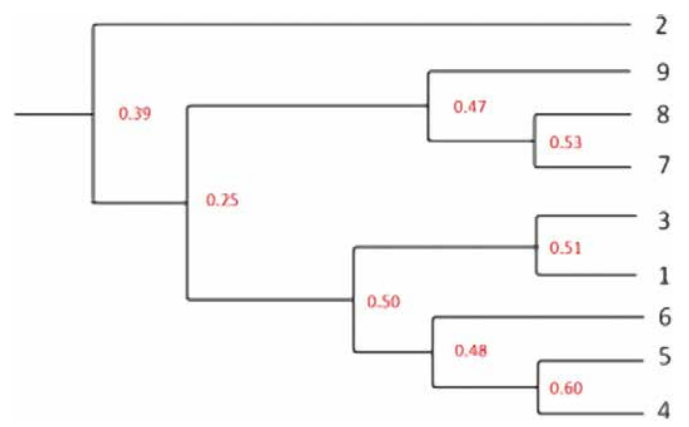

Figure 3. Similarity cluster of microbial communities among different karst microhabitats samples. Numbering is: 1. Primeval forest surface; 2. Primeval forest stone ditch; 3. Primeval forest stone seam; 4. Shrubbery soil surface; 5 . Shrubbery stone ditch; 6 . Shrubbery stone seam; 7 . Secondary soil surface; 8 . Secondary forest stone ditch; and 9 . Secondary forest stone seam. 
Table 3. The similarity index between different microhabitat samples lanes of microbial communities (\%).

\begin{tabular}{|c|c|c|c|c|c|c|c|c|c|}
\hline Lane & 1 & 2 & 3 & 4 & 5 & 6 & 7 & 8 & 9 \\
\hline 1 & 100.0 & 20.2 & 29.4 & 33.5 & 22.1 & 35.9 & 24.2 & 25.6 & 22.2 \\
\hline 2 & 20.2 & 100.0 & 48.3 & 40.5 & 48.5 & 43.1 & 47.0 & 25.1 & 30.7 \\
\hline 3 & 29.4 & 48.3 & 100.0 & 58.4 & 45.1 & 44.1 & 42.5 & 29.5 & 34.7 \\
\hline 4 & 33.5 & 40.5 & 58.4 & 100.0 & 51.3 & 44.6 & 39.6 & 35.7 & 33.5 \\
\hline 5 & 22.1 & 48.5 & 45.1 & 51.3 & 100.0 & 52.1 & 39.6 & 26.7 & 39.9 \\
\hline 6 & 35.9 & 43.1 & 44.1 & 44.6 & 52.1 & 100.0 & 40.1 & 34.1 & 29.4 \\
\hline 7 & 24.2 & 47.0 & 42.5 & 39.6 & 39.6 & 40.1 & 100.0 & 25.0 & 37.9 \\
\hline 8 & 25.6 & 25.1 & 29.5 & 35.7 & 26.7 & 34.1 & 25.0 & 100.0 & 25.0 \\
\hline 9 & 22.2 & 30.7 & 34.7 & 33.5 & 39.9 & 29.4 & 37.9 & 25.0 & 100.0 \\
\hline
\end{tabular}

Note: 1. Primeval forest surface; 2 . Primeval forest stone ditch; 3 . Primeval forest stone seam; 4 . Shrubbery soil surface 5 . Shrubbery stone ditch; 6 , Shrubbery soil stone seam; 7. Secondary forest surface; 8 . Secondary forest stone ditch; and 9 . Secondary forest stone seam.

Table 4. Shannon Index, richness and evenness of bacterial communities in different microhabitats samples.

\begin{tabular}{|c|c|c|c|}
\hline Microhabitat Samples & Shannon Index (H) & Richness (S) & Evenness (E) \\
\hline Primeval forest soil surface & 3.13 & 24 & 0.99 \\
\hline Primeval forest stone ditch & 3.48 & 33 & 1.00 \\
\hline Primeval forest stone seam & 3.54 & 35 & 1.00 \\
\hline Shrubbery forest soil surface & 3.51 & 34 & 1.00 \\
\hline Shrubbery forest stone ditch & 3.65 & 39 & 1.00 \\
\hline Shrubbery forest stone seam & 3.48 & 33 & 1.00 \\
\hline Secondary forest soil surface & 3.57 & 36 & 1.00 \\
\hline Secondary forest stone ditch & 3.38 & 30 & 0.99 \\
\hline $\begin{array}{l}\text { Secondary forest stone seam } \\
\text { Mean value }\end{array}$ & $\begin{array}{l}3.42 \\
3.46\end{array}$ & $\begin{array}{l}31 \\
32\end{array}$ & $\begin{array}{l}1.00 \\
0.99\end{array}$ \\
\hline
\end{tabular}

surface, and the order of fungal Shannon index and richness of secondary forest microhabitats and shrubbery were: soil surface $>$ stone seam $>$ stone ditch and stone ditch $>$ soil surface $>$ stone seam, respectively. However, the diversity index and abundance of different microhabitats did not show the same trend.

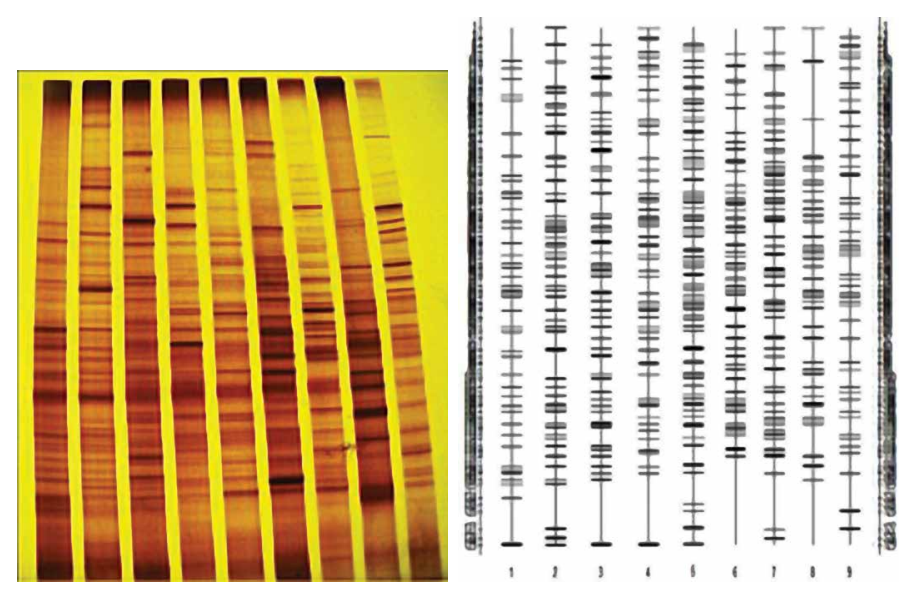

Figure 4. DGGE results of fungal communities in different karst microhabitats samples: $A=D G G E$ profile of amplified of fungal communities in different karst microbial samples, and B = DGGE sketch map of fungal communities in different karst microhabitats samples. Numbering is: 1 . Secondary forest stone seam; 2. Secondary forest stone ditch; 3 . Secondary forest soil surface; 4. Shrubbery stone seam; 5 . Shrubbery stone ditch; 6 . Shrubbery soil surface; 7. Primeval forest stone seam; 8 . Primeval forest stone ditch; and 9. Primeval forest soil surface.

\section{Genetic Diversity Characteristics of Fungi in Karst Mi- crohabitats}

DGGE Analysis of Soil Fungal Communities

The fungal communities of different soil samples were observed by DGGE (Fig. 4A). Similar to bacteria, all the lanes had a large number of bands that showed each karst microhabitat was rich in fungal diversity (Fig. 4B). There were both the conserved and specific bands among all lanes, indicating that there were both similar and specific fungal populations in the soil in different types of microhabitats in karst. It was obvious that there were more fungal bands than bacterial bands, which suggested different abundance and diversity of fungal and bacterial species in karst microhabitats. From the DGGE profile, the shrubbery forest (lane 4,5 , and 6; 52, 64, and 46 bands out of 129 , respectively) exhibited the most abundant bands, and the abundance of secondary and primeval forest was similar, which was also similar to bacteria (line 34, 38, and 37 bands out of 78 , respectively). Lane 8 from the primeval forest had the lowest quantity of bands (42 bands out of 129). The average fungal bands in stone seam were higher than those in stone ditch and soil surfaces (52 bands, 


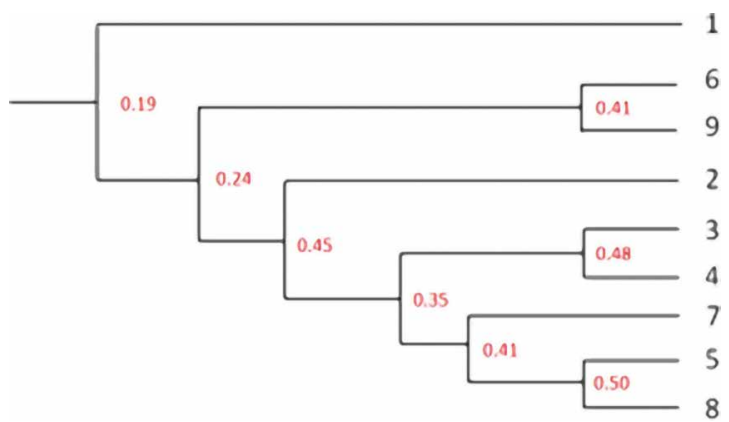

Figure 5. Similarity cluster of fungal communities among different microhabitats samples. Numbering is: 1 . Secondary forest stone seam; 2 . Secondary forest stone ditch; 3 . Secondary forest soil surface; 4. Shrubbery stone seam; 5 . Shrubbery stone ditch; 6 . Shrubbery soil surface; 7. Primeval forest stone seam; 8. Primeval forest stone ditch; and 9. Primeval forest soil surface.
45 bands, and 49 bands, all out of 127), but the bacterial bands in the three microhabitats were similar.

\section{Similarity Analysis of Fungal Communities in Different Micro- habitats}

As shown in Figure 5, the dendrogram gave rise to two main branches of clusters and shared a similarity of 0.19 (Fig. 5, Table 5). The fungal communities between secondary forest stone ditch and shrubbery stone ditch stayed closer with a high similarity of 0.50 . The similar indexes of the stone ditch of three microhabitats were similar. The primeval forest surface 9 had correlation with secondary forest surface $3(16.9 \%)$ and shrubbery soil surface $6(19.0 \%)$, which were a little low but very close. In general, the similarity index of community structure among different microhabitats was very low, indicating that there were differences in fungal community structure among different karst microhabitats.

Table 5. The similarity index of different microhabitats sample lanes of microbial communities (\%).

\begin{tabular}{|c|c|c|c|c|c|c|c|c|c|}
\hline Lane & 1 & 2 & 3 & 4 & 5 & 6 & 7 & 8 & 9 \\
\hline 1 & 100.0 & 29.0 & 26.3 & 41.2 & 35.5 & 18.0 & 17.5 & 21.8 & 17.9 \\
\hline 2 & 29.0 & 100.0 & 39.0 & 21.6 & 49.9 & 28.8 & 30.4 & 33.6 & 19.1 \\
\hline 3 & 26.3 & 39.0 & 100.0 & 26.8 & 43.9 & 42.4 & 31.5 & 25.8 & 16.9 \\
\hline 4 & 41.2 & 21.6 & 26.8 & 100.0 & 32.7 & 19.3 & 22.6 & 27.2 & 18.5 \\
\hline 5 & 35.5 & 49.9 & 43.9 & 32.7 & 100.0 & 34.7 & 34.4 & 38.2 & 33.7 \\
\hline 6 & 18.0 & 28.8 & 42.4 & 19.3 & 34.7 & 100.0 & 48.2 & 33.2 & 19.0 \\
\hline 7 & 17.5 & 30.4 & 31.5 & 22.6 & 34.4 & 48.2 & 100.0 & 34.7 & 30.1 \\
\hline 8 & 21.8 & 33.6 & 25.8 & 27.2 & 38.2 & 33.2 & 34.7 & 100.0 & 16.5 \\
\hline 9 & 17.9 & 19.1 & 16.9 & 18.5 & 33.7 & 19.0 & 30.1 & 16.5 & 100.0 \\
\hline
\end{tabular}

Note: 1 . Secondary forest stone seam; 2 . Secondary forest stone ditch; 3 . Secondary forest surface; 4 . Shrubbery soil stone seam; 5 . Shrubbery stone ditch; 6 . Shrubbery soil surface; 7. Primeval forest stone seam; 8 . Primeval forest stone ditch; 9. Primeval forest surface.

\section{Fungal Diversity and Richness Analysis}

We then calculated the diversity index of soil fungal communities in different karst microhabitats samples by Shannon index $(\mathrm{H})$, richness $(\mathrm{S})$ and evenness $(\mathrm{E})$ (Table 6). The highest diversity index of karst microhabitats fungi was primeval forest stone seam (4.11 and 62), shrubbery forest stone ditch (4.32 and 76) and stone seam (4.10 and 61). The lowest diversity index of all the microhabitats were primeval forest stone ditch ( 3.75 and 43 ) and secondary forest stone seam (3.78 and 44). The mean value in fungal Shannon index among different microhabitats was 3.99. There was no difference among the evenness from the nine types of microhabitats. The trend of fungal Shannon index and the richness of primeval forest microhabitats was: stone seam $>$ stone ditch $>$ surface, and the trends of fungal Shannon index

Table 6. Shannon index, richness and evenness of fungal communities in different karst microhabitats samples.

\begin{tabular}{cccc}
\hline Microhabitat samples & Shannon index (H) & Richness (S) & Evenness (E) \\
\hline Primeval forest surface & 3.90 & 40 & 43 \\
Primeval forest stone ditch & 3.75 & 62 & 1.00 \\
Primeval forest stone seam & 4.11 & 53 & 76 \\
Shrubbery forest surface & 3.96 & 61 & 1.00 \\
Shrubbery forest stone ditch & 4.32 & 54 & 1.00 \\
Shrubbery forest stone seam & 4.10 & 55 & 1.00 \\
Secondary forest surface & 3.98 & 4.00 \\
Secondary forest stone ditch & 4.00 & 3.00 & 1.00 \\
Secondary forest stone seam & 3.99 & 55 & 1.00 \\
Mean value & & 48 &
\end{tabular}



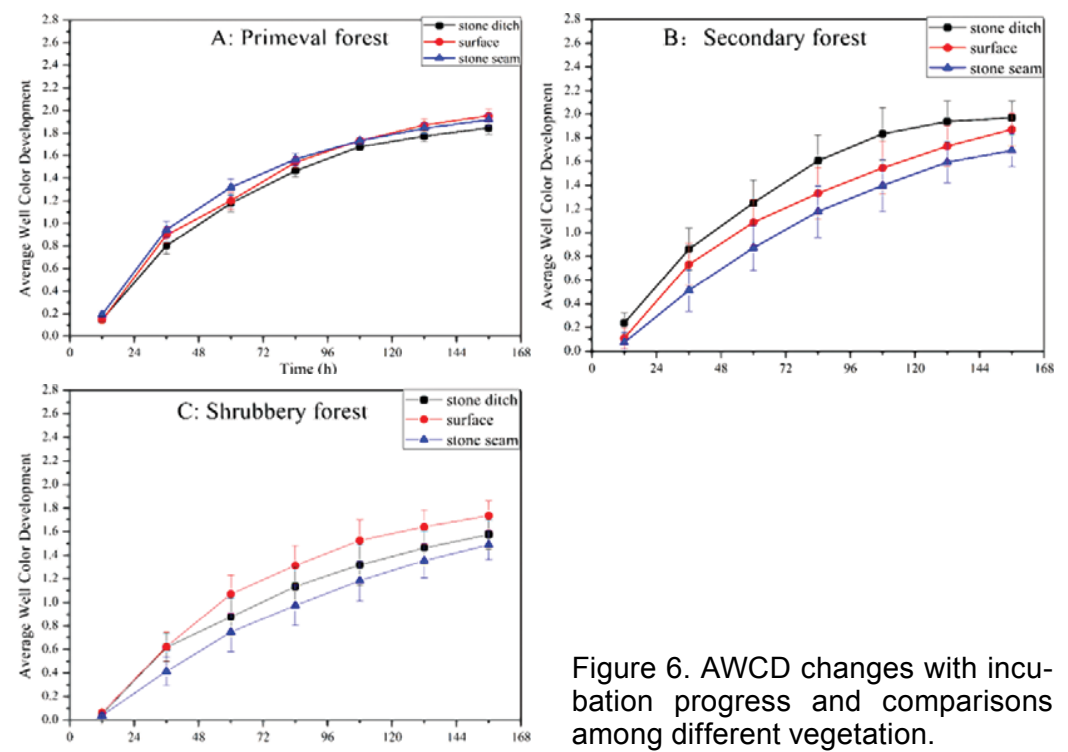

Figure 6. AWCD changes with incubation progress and comparisons among different vegetation.
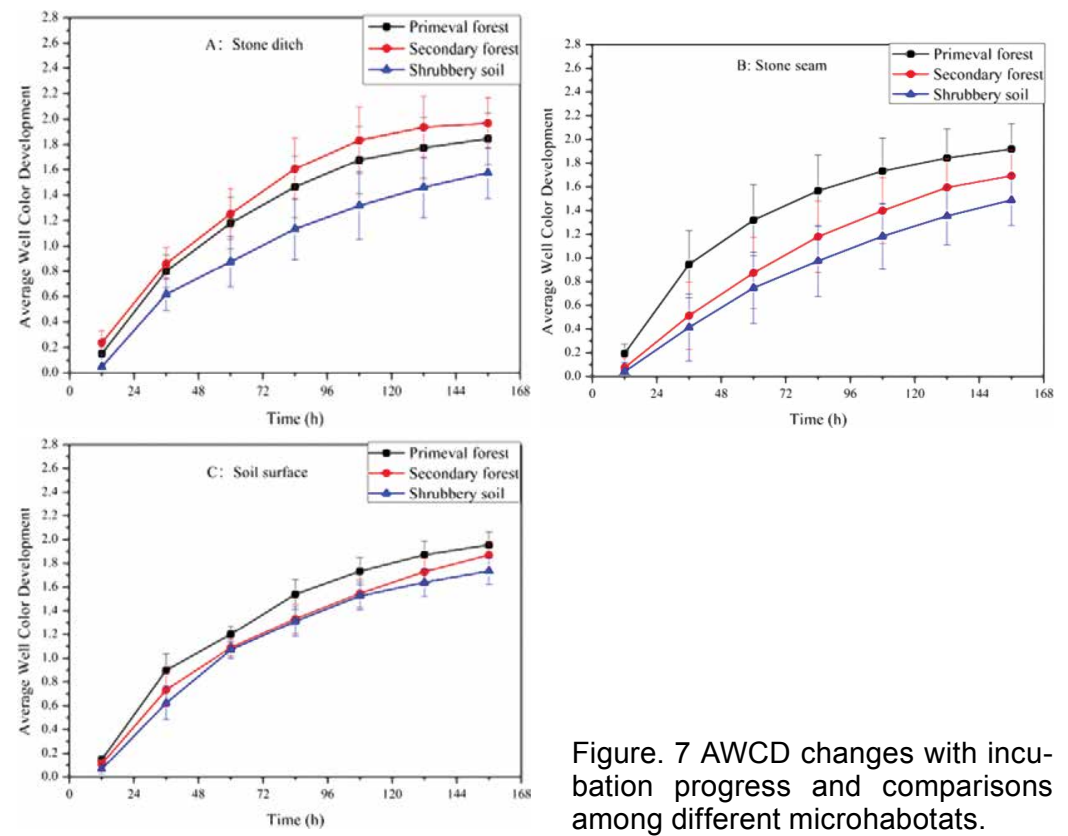

Figure. 7 AWCD changes with incubation progress and comparisons among different microhabotats. and richness of secondary forest microhabitats and shrubbery were: stone ditch $>$ surface $>$ stone seam and stone ditch $>$ stone seam $>$ surface, respectively.

\section{Awcd Analysis of Microbial Diversity in Karst Microhabitats}

Average Well Color Development (AWCD) using Biolog EcoPlates is used to indicate the activity of soil microorganisms and the ability of soil microorganisms to use single carbon sources, and it could reflect soil microbial activity and microbial community physiological functional diversity (Miao et al., 2019). The density and activity of bacteria increased with the AWCD. Conversely, the lower the AWCD value would indicate lower bacterial density and lower activity. We accessed the different microhabitats of the same sample plot (Fig. 6). The AWCD values of the primeval forest including stone ditch, stone seam, and soil surface did not show differences, which indicated that the activity values were basically the same (Fig. 6A). The AWCD values and microbial activity of the secondary forest were obviously different during the growth period and the trend of three microhabitats was: soil surface $>$ stone ditch $>$ stone seam (Fig. 6B). The study accessed the same microhabitats of different sample vegetation (Fig. 7A-C). The AWCD values of three different types of vegetation in the stone ditch were different and the trend was: secondary forest $>$ primeval forest $>$ shrubbery forest (Fig. 7A). The three AWCD curves of the stone seam and soil surface were clearly different and the trend of microbial activity was the same: primeval forest $>$ secondary forest $>$ shrubbery forest (Fig. 7E-F).

\section{Diversity Index of Soil Microbial Community Metabolism Function}

Shannon's diversity index indicates functional diversity, which means that the number of carbon sources used by soil microbial communities of all the ecosystems when the color change rate is consistent. For example, the bigger the Shannon index is the higher is the soil microbial community functional diversity. McIntosh index includes the number of species (richness) and the evenness of individual distribution in species. The diversity will become higher as the number of microbial types increases. Similarly, an increase in the evenness of individual distribution among species will also increase the functional diversity. The Simpson index is always used to access the dominant species (Ma, 2019). Table 7 shows the diversity index based on 96 hours of data. In the primeval forest, the Shannon's diversity indexes of three kinds of microhabitats were: stone ditch $>$ soil surface $>$ stone seam (Table 7). As for secondary and shrubbery forest, the trends of Shannon's diversity index were stone ditch $>$ soil surface $>$ stone seam and soil surface $>$ stone ditch $>$ stone seam, respectively. On the whole, the highest Shannon's diversity index was the secondary forest stone ditch (3.29), while the lowest was the secondary stone seam (3.15). The Simpson indexes of all investigated karst microhabitats were between 0.95-0.96, which were not different. The Mclntosh indexes of karst microhabitats in primeval forest were different. The trend was: stone seam $>$ soil surface $>$ stone ditch. In the secondary forest microhabitats, the Mclntosh index of stone ditch $>$ soil surface $>$ stone seam. The trend of Mclntosh index of shrubbery forest was: soil surface > stone ditch > stone seam, which was also different among primeval and secondary forest. Overall, the highest and lowest evenness index was the primeval stone seam (10.28) and shrubbery stone seam (6.79). 
Table 7. Shannon's diversity index, Simpson index and Mcintosh index of nine karst microhabitats.

\begin{tabular}{|c|c|c|c|}
\hline Sample & Shannon Index & Simpson Index & Mclntosh Index \\
\hline Primeval forest soil surface & $3.25 \pm 0.05$ & $0.958 \pm 0.002$ & $10.19 \pm 0.61$ \\
\hline primeval forest stone ditch & $3.26 \pm 0.01$ & $0.959 \pm 0.000$ & $9.62 \pm 0.90$ \\
\hline Primeval forest stone seam & $3.19 \pm 0.04$ & $0.955 \pm 0.002$ & $10.65 \pm 0.71$ \\
\hline Secondary forest soil surface & $3.20 \pm 0.04$ & $0.955 \pm 0.002$ & $9.15 \pm 0.46$ \\
\hline Secondary forest stone ditch & $3.29 \pm 0.04$ & $0.960 \pm 0.002$ & $10.28 \pm 1.14$ \\
\hline Secondary forest stone seam & $3.13 \pm 0.04$ & $0.951 \pm 0.002$ & $8.39 \pm 0.60$ \\
\hline Shrubbery soil surface & $3.21 \pm 0.02$ & $0.956 \pm 0.001$ & $8.79 \pm 0.56$ \\
\hline Shrubbery stone ditch & $3.18 \pm 0.05$ & $0.955 \pm 0.003$ & $7.78 \pm 0.94$ \\
\hline Shrubbery stone seam & $3.15 \pm 0.06$ & $0.952 \pm 0.004$ & $6.79 \pm 0.86$ \\
\hline
\end{tabular}

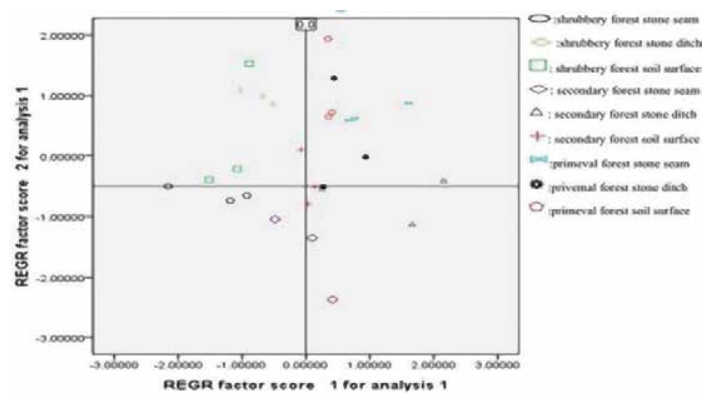

Figure 8. PCA of soil microbial carbon source utilization diversity of different karst microhabitats.
Principal Component Analysis (PCA) of Soil Microbial Carbon Source Utilization

Different microhabitats showed differences on PC1 and PC2, indicating that their soil microorganisms do use different carbon sources (Fig. 8, Tables 2 and 8). The significance value less than 0.05 have been marked in red. The significant value is less than 0.05 , indicating that the two objects have significant differences. Further variance analysis of the scoring coefficients of the principal components of carbon sources in different microhabitat habitats showed that on PC1, the soil microbial metabolism patterns in three types of microhabitats (stone seam, stone ditch, and soil surfaces of shrubbery forest) were not significantly different. In the secondary forest plots, there were significant

differences in the metabolic patterns between the stone seam and stone ditch, and between the stone ditch and the soil surface, but there was no significant difference in the metabolic patterns between the stone seam and the soil surface. On PC2, there were significant differences between the stone seam and the soil surface of the shrub forest, and there were no significant differences between the stone seam and the ditch, and between the stone ditch and the soil surface. There was no significant difference in the soil surface, stone seam, and stone ditch in the primeval forest. As for carbon resources analysis, there were five kinds of amino acids, four kinds of carbohydrates, three kinds of polymers, two kinds of carboxylic acids and amines, and one kind of amphiphilic compound showing significant relation to PC1, which indicated that the main carbon resources influenced PC1 were amino acids, carbohydrates, and polymers. Similarly, among the carbon sources that were significantly related to PC2, the carbon source affecting PC2 was mainly the carbohydrates because of six carbohydrates of PC2. In summary, the carbon sources that differentiated the microhabitat soil microbial metabolism patterns were mainly carbohydrates, amino acids, and polymers.

\section{DISCUSSION}

Karst microhabitats are special and unique environmental units and have different effects on ecological environments in karst regions. Soil microorganisms are very important to the ecological restoration in karst regions. At different stages of desertification, the number and distribution of microorganisms are also different. Therefore, the soil microbiome can be a good indicator of soil quality and soil health in the karst rocky desertification regions (Tang et al., 2019). In fact, soil microorganisms in different microhabitats have different distributions and structural features that may indicate the role of soil microorganisms, such as bacteria and fungi, would also be different. The relationship between genetic and functional diversity in different microhabitats and soil microbial diversity is more direct. Some existing studies have ignored the various characteristics and roles of soil microorganisms in the microhabitats (Yu et al., 2004; Wei et al., 2008). Our experiments made up for this shortcoming to some degree and more comprehensively considered and studied the genetic and functional diversity of bacteria and fungi in different karst microhabitats, which may provide new insights into ecological restoration and rocky desertification management in karst regions.

There many ways to study microbial diversity in different microhabitats. Our study showed that the diversity of bacteria and fungi in microhabitats of the karst could be detected by PCR-DGGE. Wu et al. (2019) used phospholipid fatty acid (PLFA) technology to study the bacterial and fungal diversity in Maolan Natural Nature Reserve. The trends of diversity were: the stone trough $>$ the stone ditch $>$ the soil surface $>$ the stone cave $>$ the stone seam, which were similar to our result. Liao et al. (2013b) used substrate-induced respiration to access the amount of the soil microbial biomass in karst regions in Huajiang dry hot valley watershed in Guizhou Province. The results showed that the substrate-induced respiration of soil from their stone ditch was relatively high in all microhabitats investigated. 
Table 8. The Principle Component scores for different microhabitats.

\begin{tabular}{|c|c|c|c|c|c|c|c|}
\hline \multirow[b]{2}{*}{ Dependent Variable } & \multirow[b]{2}{*}{$\begin{array}{c}\text { (I) } \\
\text { VAvR00001 }\end{array}$} & \multirow[b]{2}{*}{$\begin{array}{c}\text { (J) } \\
\text { VAR00001 }\end{array}$} & \multirow[b]{2}{*}{$\begin{array}{c}\text { Mean } \\
\text { Difference (I-J) }\end{array}$} & \multirow[b]{2}{*}{ Std. Error } & \multirow[b]{2}{*}{ Signifcance } & \multicolumn{2}{|c|}{$\begin{array}{c}\text { 95\% Confidence } \\
\text { Interval }\end{array}$} \\
\hline & & & & & & $\begin{array}{l}\text { Lower } \\
\text { Bound }\end{array}$ & $\begin{array}{l}\text { Upper } \\
\text { Bound }\end{array}$ \\
\hline \multirow[t]{9}{*}{$\begin{array}{l}\text { REGR factor score } 1 \text { for } \\
\text { analysis } 1\end{array}$} & 1 & $\begin{array}{l}2 \\
3\end{array}$ & $\begin{array}{l}0.46562679 \\
0.64492381\end{array}$ & $\begin{array}{l}0.40115217 \\
0.40115217\end{array}$ & $\begin{array}{l}0.261 \\
0.125\end{array}$ & $\begin{array}{l}-0.3771627 \\
-0.1978656\end{array}$ & $\begin{array}{l}1.3084162 \\
1.4877133\end{array}$ \\
\hline & 2 & $\begin{array}{l}1 \\
3\end{array}$ & $\begin{array}{c}-0.46562679 \\
0.17929703\end{array}$ & $\begin{array}{l}0.40115217 \\
0.40115217\end{array}$ & $\begin{array}{l}0.261 \\
0.660\end{array}$ & $\begin{array}{r}-1.3084162 \\
-0.6634924\end{array}$ & $\begin{array}{l}0.3771627 \\
1.0220865\end{array}$ \\
\hline & 3 & $\begin{array}{l}1 \\
2\end{array}$ & $\begin{array}{l}-0.64492381 \\
-0.17929703\end{array}$ & $\begin{array}{l}0.40115217 \\
0.40115217\end{array}$ & $\begin{array}{l}0.125 \\
0.660\end{array}$ & $\begin{array}{l}-1.4877133 \\
-1.0220865\end{array}$ & $\begin{array}{l}0.1978656 \\
0.6634924\end{array}$ \\
\hline & 4 & $\begin{array}{l}5 \\
6\end{array}$ & $\begin{array}{l}-1.34571883^{a} \\
-0.02245966\end{array}$ & $\begin{array}{l}0.40115217 \\
0.40115217\end{array}$ & $\begin{array}{l}0.004^{a} \\
0.956\end{array}$ & $\begin{array}{l}-2.1885083 \\
-0.8652491\end{array}$ & $\begin{array}{c}-0.5029294 \\
0.8203298\end{array}$ \\
\hline & 5 & $\begin{array}{l}4 \\
6\end{array}$ & $\begin{array}{l}1.34571883^{a} \\
1.32325917^{a}\end{array}$ & $\begin{array}{l}0.40115217 \\
0.40115217\end{array}$ & $\begin{array}{l}0.004^{\mathrm{a}} \\
0.004^{\mathrm{a}}\end{array}$ & $\begin{array}{l}0.5029294 \\
0.4804697\end{array}$ & $\begin{array}{l}2.9387222 \\
2.1885083\end{array}$ \\
\hline & 6 & $\begin{array}{l}4 \\
5\end{array}$ & $\begin{array}{r}0.02245966 \\
-1.32325917^{\mathrm{a}}\end{array}$ & $\begin{array}{l}0.40115217 \\
0.40115217\end{array}$ & $\begin{array}{l}0.956 \\
0.004^{a}\end{array}$ & $\begin{array}{l}-0.8203298 \\
-2.1660486\end{array}$ & $\begin{array}{c}0.8652491 \\
-0.4804697\end{array}$ \\
\hline & 7 & $\begin{array}{l}8 \\
9\end{array}$ & $\begin{array}{l}-0.26144823 \\
-0.68163703\end{array}$ & $\begin{array}{l}0.40115217 \\
0.40115217\end{array}$ & $\begin{array}{l}0.523 \\
0.106\end{array}$ & $\begin{array}{l}-1.1042377 \\
-1.5244265\end{array}$ & $\begin{array}{l}0.5813412 \\
0.1611524\end{array}$ \\
\hline & 8 & $\begin{array}{l}7 \\
9\end{array}$ & $\begin{array}{r}0.26144823 \\
-0.42018880\end{array}$ & $\begin{array}{l}0.40115217 \\
0.40115217\end{array}$ & $\begin{array}{l}0.523 \\
0.309\end{array}$ & $\begin{array}{l}-0.5813412 \\
-1.2629782\end{array}$ & $\begin{array}{l}1.1042377 \\
0.4226006\end{array}$ \\
\hline & 9 & $\begin{array}{l}7 \\
8\end{array}$ & $\begin{array}{l}0.68163703 \\
0.42018880\end{array}$ & $\begin{array}{l}0.40115217 \\
0.40115217\end{array}$ & $\begin{array}{l}0.106 \\
0.309\end{array}$ & $\begin{array}{r}-0.1611524 \\
-0.4226006\end{array}$ & $\begin{array}{l}1.5244265 \\
1.2629782\end{array}$ \\
\hline \multirow[t]{9}{*}{$\begin{array}{l}\text { REGR factor score for } \\
\text { analysis } 1\end{array}$} & 1 & $\begin{array}{l}2 \\
3\end{array}$ & $\begin{array}{r}0.43734062 \\
-0.41109415\end{array}$ & $\begin{array}{l}0.50234562 \\
0.50234562\end{array}$ & $\begin{array}{l}0.395 \\
0.424\end{array}$ & $\begin{array}{l}-0.6180484 \\
-1.4664831\end{array}$ & $\begin{array}{l}1.4927296 \\
1.6442948\end{array}$ \\
\hline & 2 & $\begin{array}{l}1 \\
3\end{array}$ & $\begin{array}{l}-0.43734062 \\
-0.84843477\end{array}$ & $\begin{array}{l}0.50234562 \\
0.50234562\end{array}$ & $\begin{array}{l}0.395 \\
0.108\end{array}$ & $\begin{array}{l}-1.4927296 \\
-1.9038238\end{array}$ & $\begin{array}{l}0.6180484 \\
0.2069542\end{array}$ \\
\hline & 3 & $\begin{array}{l}1 \\
2\end{array}$ & $\begin{array}{l}0.41109415 \\
0.84843477\end{array}$ & $\begin{array}{l}0.50234562 \\
0.50234562\end{array}$ & $\begin{array}{l}0.424 \\
0.108\end{array}$ & $\begin{array}{l}-0.6442948 \\
-0.2069542\end{array}$ & $\begin{array}{l}1.4664831 \\
1.9038238\end{array}$ \\
\hline & 4 & $\begin{array}{l}5 \\
6\end{array}$ & $\begin{array}{l}-0.88944052 \\
-1.19088983\end{array}$ & $\begin{array}{l}0.50234562 \\
0.50234562\end{array}$ & $\begin{array}{l}0.094 \\
0.029^{\mathrm{a}}\end{array}$ & $\begin{array}{l}-1.9448295 \\
-2.2462788\end{array}$ & $\begin{array}{r}0.1659485 \\
-0.1355009\end{array}$ \\
\hline & 5 & $\begin{array}{l}4 \\
6\end{array}$ & $\begin{array}{r}0.88944052 \\
-0.30144931\end{array}$ & $\begin{array}{l}0.50234562 \\
0.50234562\end{array}$ & $\begin{array}{l}0.094 \\
0.556\end{array}$ & $\begin{array}{l}-0.1659485 \\
-1.3568383\end{array}$ & $\begin{array}{l}1.9448295 \\
0.7539397\end{array}$ \\
\hline & 6 & $\begin{array}{l}4 \\
5\end{array}$ & $\begin{array}{l}1.19088983^{a} \\
0.30144931\end{array}$ & $\begin{array}{l}0.50234562 \\
0.50234562\end{array}$ & $\begin{array}{l}0.029^{a} \\
0.556\end{array}$ & $\begin{array}{c}0.1355009 \\
-0.7539397\end{array}$ & $\begin{array}{l}2.2462788 \\
1.3568383\end{array}$ \\
\hline & 7 & $\begin{array}{l}8 \\
9\end{array}$ & $\begin{array}{l}-0.93958746 \\
-1.61499360^{\mathrm{a}}\end{array}$ & $\begin{array}{l}0.50234562 \\
0.50234562\end{array}$ & $\begin{array}{l}0.078 \\
0.005^{\mathrm{a}}\end{array}$ & $\begin{array}{l}-1.9949764 \\
-2.6703826\end{array}$ & $\begin{array}{r}0.1158015 \\
-0.5596046\end{array}$ \\
\hline & 8 & $\begin{array}{l}7 \\
9\end{array}$ & $\begin{array}{r}0.93958746 \\
-0.67540615\end{array}$ & $\begin{array}{l}0.50234562 \\
0.50234562\end{array}$ & $\begin{array}{l}0.078 \\
0.195\end{array}$ & $\begin{array}{l}-0.1158015 \\
-1.7307951\end{array}$ & $\begin{array}{l}1.9949764 \\
0.3799828\end{array}$ \\
\hline & 9 & $\begin{array}{l}7 \\
8\end{array}$ & $\begin{array}{l}1.61499360^{a} \\
0.67540615\end{array}$ & $\begin{array}{l}0.50234562 \\
0.50234562\end{array}$ & $\begin{array}{l}0.005^{\mathrm{a}} \\
0.195\end{array}$ & $\begin{array}{c}0.5596046 \\
-0.3799828\end{array}$ & $\begin{array}{c}2.6703826 \\
1.7307951\end{array}$ \\
\hline
\end{tabular}

a The mean difference is significant at the 0.05 level.

Note: 1. Primeval forest stone seam; 2 . Primeval stone ditch; 3 . Primeval soil surface; 4 . Secondary forest stone seam; 5 . Secondary forest stone ditch; 6 . Secondary soil surface; 7. Shrubbery stone seam; 8 . Shrubbery stone ditch; 9 . Shrubbery soil surface;

\section{Effects oOf Karst Microhabitats on Soil Microbial Genetic Diversity}

In our study, the karst microhabitats investigated had abundant bacterial and fungal communities and functional diversity. The bacterial communities among nine research sites do have differences. Cluster analysis (Fig. 3) indicated that the bacterial community structure of different microhabitats under the same vegetation type was more similar than that of similar microhabitats under different vegetation types. The vegetation, rather than microhabitats, was more important to the distribution of bacteria in karst. In previous studies, we could demonstrate that the differences in the karst microhabitats soil heterogeneity were manifested by changes in clay particles, micro-aggregates, and effective nutrient quantities (Zhou and Lei, 2007; Wakerlin et al., 2008; Zhang et al., 2015). All the factors could influence the bacterial diversity on a high level, which was also the reason why the bacterial community structure was different among all kinds of microhabitats. Vegetation is an important source of soil nutrients. Microorganism distribute by the types and amount of plant litter and the rate of water loss from the soil surface. Under the same vegetation, the structure and kind of soil carbon and nitrogen resources are basically consistent, while other factors including soil water content, temperature, $\mathrm{pH}$, aeration, physical structure, and the organic content could be different (Murugan et al., 2014; Ren et al., 2018). Therefore, our study shows that the bacterial community structure was mainly controlled by the composition of carbon source at the micro-geomorphic scale of microhabitats. 
The distribution of fungi was sensitive to changes in environmental factors that may lead to changes in diversity. The heterogeneity of different microhabitats is high in water content, heat, light, and soil fungal diversity. The heterogeneity may be the reason why the fungal diversity may be lower than bacterial diversity in different microhabitats. According to the phylogenetic tree (Fig. 5) for fungi, similar microhabitats in different vegetation types were more similar than those in the same vegetation type. The impact of microhabitats on its diversity and community structure was greater than the impact of vegetation types on its diversity, which was opposite to bacterial diversity. Our research indicated that the spatial heterogeneity had different influences on the bacteria and fungi. Many studies had illustrated that the soil organic content could significantly influence the soil fungal community structure (Fan et al., 2012; Chen et al., 2016; 2017).

$\mathrm{Hu}$ et al. (2016) employed site comparisons of Chinese toona reforestation to study the relationship among soil microbial biomass carbon (MBC), microbial biomass nitrogen, and other organic matter and soil microbial community structure and diversity. Their results showed that the microbial biomass and activity of reforested soil were higher, which meant that the vegetation could increase the microbial diversity by increasing the content of soil organic matter. The complexity of vegetation carbon sources, the organic matter imported, and the spatial and temporal differences of carbon sources in the same system are three important factors influencing soil fungal functional diversity. The spatial and temporal differential may have a closer connection with the fungal community functional diversity in karst regions because the fungal community structure and abundance of different microhabitats of the same vegetation type were both different. In fact, the dominant species of fungi among different microhabitats were very different, which indicated that for a single karst vegetation type or ecosystem, the microhabitats within it could play all kinds of roles on the whole material cycle by changing microbial structure and dominant species. In the future, when carrying out karst ecosystem protection and rocky desertification restoration, it is necessary not only to pay attention to the role of the microhabitat, but also to take into account differences in the ecological effectiveness of the microhabitat in different restoration stages.

\section{Effects of Karst Microhabitats on Soil Microbial Functional Diversity}

Among the three vegetation types, the metabolic activities of the three types of microhabitat in each plot were different. The differences were not obvious in the primary forest, but reached a significant level in the secondary and shrub forest. On the whole, the karst microhabitats had a significant impact on the soil microbial activity. The trend of microbial activity of three types of microhabitats was: stone ditch $>$ soil surface $>$ stone seam, possibly due to structural differences among the karst microhabitats. The stone seam is relatively closed with small openings and weak material accumulation, leading to lower microbial activity than other microhabitats. The stone ditch and soil surface are relatively open to the environment with a large area and a large amount of litter accumulation. Litter could provide rich carbon sources during the decomposition process (Zhu et al., 2012) that is beneficial to the microbial growth and material cycle (Liao et al., 2012; 2013a). The changing trends of AWCD of three samples were basically maintained in primary forest $>>$ secondary forest $>$ shrubbery forest, indicating that the vegetation degradation or reverse succession would decrease soil microbial activity of all microhabitats, even the whole ecosystem microbial activity consistent with the study by Zhu et al. (2012). The microbial metabolism patterns of the three types of microhabitats under the same vegetation type showed basically no significant differences, while the microbial metabolism patterns of the same vegetation type under the same microhabitats showed significant differences. According to the results of AWCD, for samples of the same vegetation type, the heterogeneity brought by different microhabitats was mainly reflected in the number of single populations of microorganisms rather than microbial community structure, so the metabolic pattern did not change. However, the change of vegetation types would affect the community structure and the number of single populations of microorganisms simultaneously, which made the metabolic patterns different from each other. In conclusion, the vegetation may be the main factor influencing soil microbial metabolic patterns in karst regions.

\section{ACKNOWLEDGMENTS}

This work was supported by the Special Project of Technology Development and Research of Scientific Research Institute of Ministry of Science and Technology (No.2014EG166135); National Natural Science Foundation of China (No. 41977294).

\section{REFERENCES}

Agryzkov, T., Tortosa, L., and Vicent, J.F., 2018, An algorithm to compute data diversity index in spatial networks: Applied Mathematics and Computation, v. 337, p. 63-75. https://doi.org/10.1016/j.amc.2018.04.068

Bai, X.Y., Wang, S.J., and Xiong, K.N., 2013, assessing spatial-temporal evolution processes of karst rocky desertification land: indications for restoration strategies: Land Degradation \& Development, v. 24, no. 1, p. 47-56. https://doi.org/10.1002/ldr.1102

Bai, Y.X., and Zhou, Y.C., 2020, The main factors controlling spatial variability of soil organic carbon in a small karst watershed, Guizhou Province, China: Geoderma, v. 357. https://doi.org/10.1016/j.geoderma.2019.113938

Bassam, B.J., Caetano-Anollks, G., and Gresshoff, P.M., 1991, Fast and sensitive silver staining of DNA in Polyacrylamide Gels: Analytical Biochemistry v. 196, p. 80-83. https://doi.org/10.1016/0003-2697(91)90120-I 
Chen, D.M., Duan, Y.Q., Yang, Y.H., Jin, Y., and Yuan, L., 2016, Influence of crop rotation on enzyme activities and fungal communities in fluecured tobacco soil: Acta Ecologica Sinica, v. 36, p. 2373-2381. https://doi.org/10.5846/stxb201411052183

Chen, H., Li, D., Mao, Q., Xiao, K., and Wang, K., 2019, Resource limitation of soil microbes in karst ecosystems: Science of the Total Environment, v. 650, no. Pt 1, p. 241-248. https://doi.org/10.1016/j.scitotenv.2018.09.036

Chen, Z.H., Liang, X., Li, Y.C., Li, Y.F., Xu, Q.F., Wu, Q.F., Li, S.H., and Shen, Z.M., 2017, Effects of different fertilization regimes on soil fungal communities under Phyllostachys violascens stand: Chinese Journal of Applied Ecology, v. 28, p. 1168-1176. https://doi.org/10.13287 /j.1001-9332.201704.002

Dassen, S., Cortois, R., Martens, H., de Hollander, M., Kowalchuk, G.A., Van der Putten, W.H., and De Deyn, G.B., 2017, Differential responses of Soil Bacteria, Fungi, Archaea and Protists to plant species richness and plant functional group identity: Molecular Ecology, v. 26, no. 15, p. 4085-4098. https://doi.org/10.1111/mec.14175

Deng, Y., Wang, S., Bai, X., Luo, G., Wu, L., Chen, F., Wang, J., Li, Q., Li, C., Yang, Y., Hu, Z., and Tian, S., 2020, Spatiotemporal dynamics of soil moisture in the karst areas of China based on reanalysis and observations data: Journal of Hydrology, v. 585. https://doi.org/10.1016/j. jhydrol.2020.124744

Du, X.L., and Wang, S.J., 2010, Micro-habitat characteristics in the karst desertification area: a case study of the Wangjiazhai Catchment in Guizhou Province: Earth and Environment, v. 38, p. 255-261. https://doi.org/10.14050/j.cnki.1672-9250.2010.03.009

Fan, F., Li, Z., Wakelin, S.A., Yu, W., and Liang, Y., 2012, Mineral fertilizer alers cellulolytic community structure and suppresses soil cellobiohydrolase activity in a long-term fertilization experiment: Soil Biology and Biochemistry, v. 55, p. 70-77. https://doi.org/10.1016/j.soilbio.2012.06.008

Gregorutti, V.C., and Caviglia, O.P., 2019, Impact of crop aerial and root biomass inputs on soil nitrifiers and cellulolytic microorganisms: Soil and Tillage Research, v. 191, p. 85-97. https://doi.org/10.1016/j.still.2019.03.018

Guo, P., Zhu, L., Wang, J., Wang, J., and Liu, T., 2015, Effects of alkyl-imidazolium ionic liquid [Omim]Cl on the functional diversity of soil microbial communities: Environmental Science and Pollution Research International, v. 22, no. 12, p. 9059-9066. https://doi.org/10.1007/s11356-0144052-8

Han, G., Tang, Y., and Tan, Q., 2008, Geochemical composition of rainwater in karst forest: Case study of Maolan Nature Reserve, Guizhou Province: Bulletin of Mineralogy, Petrology and Geochemistry, v. 27, p. 363-368 https://doi.org/CNKI:SUN:KYDH.0.2008-04-009

Hu, N., Li, H., Tang, Z., Li, Z., Li, G., Jiang, Y., Hu, X., and Lou, Y., 2016, Community size, activity and C:N stoichiometry of soil microorganisms following reforestation in a karst region: European Journal of Soil Biology, v. 73, p. 77-83. https://doi.org/10.1016/j.ejsobi.2016.01.007

Hui, N., Sun, N., Du, H., Umair, M., Kang, H., Liu, X., Romantschuk, M., Liu, C., 2019, Karst rocky desertification does not erode ectomycorrhizal fungal species richness but alters microbial community structure: Plant and Soil, v. 445, no. 1-2, p. 383-396. https://doi.org/10.1007/s11104019-04319-z

Jin, Z.L., Liu, G.P., Zhou, M.T., and Xu, W.-N., 2019, Indicative function of soil microbial community on soil nutrients in karst mountain grassland: Southwest China Journal of Agricultural Sciences, v. 32, p. 2638-2645. https://doi.org/10.16213/j.cnki.scjas.2019.11

Liang, X., Ren, H.D, Li, S., Leng, X.H, and Yao, X.H, 2017, Soil bacterial community structure and co-occurrence pattern during vegetation restoration in karst rocky desertification area: Frontiers in Microbiology, v. 8, p. 2377. https://doi.org/10.3389/fmicb.2017.02377

Liao, H.K., Jiang, L., Li, J., Yang, J.J., and Feng, Y.Q., 2012, Distribution characteristics of soil carbon and nitrogen under different vegetation types in micro-habitats of karst dry-hot valley region of south western China: Soils, v. 44, p. 421-428.

Liao, H.K., Li, J., and Long, J., 2013a, Effect of vegetation type and micro-habitat on soil active organic carbon and basal respiration in karst dry and hot valley region of Guizhou Province, China: Chinese Journal of Soil Science, v. 44, p. 580-586. https://doi.org/10.19336/j.cnki. trtb.2013.03.012

Liao, H.K., Li, J., Long, J., Zhang, W.J., and Liu, L.F., 2013b, Soil characteristics of different microhabitats of Chinese prickly ash in karst mountain areas of Guizhou Province: Journal of Agro-Environment Science, v. 32, p. 2429-2435. https://doi.org/10.11654/jaes.2013.12.016

Ling, Y., Li, W., Tong, T., Li, Z., Li, Q., Bai, Z., Wang, G., Chen, J., and Wang, Y., 2020, Assessing the microbial communities in four different Daqus by using PCR-DGGE, PLFA, and Biolog Analyses: Polish Journal of Microbiology, no. 69, p. 27-37. https://doi.org/10.33073/pjm-2020004

Liu, Y., Li, L.L, Zhao, K., Wang, L.L, and Rao, Y., 2004, Analysis on physical feature of karst mountains desertification soil under different land use: Journal of Soil and Water Conservation, v. 18, p. 142-145. https://doi.org/10.13870/j.cnki.stbcxb.2004.05.035

Ma, J., 2019, Generalised grey target decision method for mixed attributes based on the improved Gini-Simpson Index: Soft Computing, v. 23, no. 24, p. 13449-13458. https://doi.org/10.1007/s00500-019-03883-x

Ma Y., Holmstrm, C., Webb, J., and Leberg, S.F.K., 2003, Application of Denaturing Gradient Gel Electrophoresis (DGGE) in microbial ecology: Acta Ecologica Sinica, v. 23, p. 1561-1569.

Miao, L., Guo, S., Liu, Z., Liu, S., You, G., Qu, H., and Hou, J., 2019, Effects of nanoplastics on freshwater biofilm microbial metabolic functions as determined by BIOLOG ECO Microplates: International Journal of Environmental Research and Public Health, v. 16, no. 23. https://doi. org/10.3390/ijerph16234639

Murugan, R., Beggi, F., and Kumar, S., 2014, Belowground carbon allocation by trees, understory vegetation and soil type alter microbial community composition and nutrient cycling in tropical Eucalyptus plantations: Soil Biology and Biochemistry, v. 76, p. 257-267. https://doi org/10.1016/j.soilbio.2014.05.022

Muyzer, G., and Smalla, K., 1998, Application of Denaturing Gradient Gel Electrophoresis (DGGE) and Temperature Gradient Gel Electrophoresis (TGGE) in microbial ecology: Antonie van Leeuwenhoek International Journal of General and Molecular Microbiology, v. 73, p. 127-141. https://doi.org/10.1023/A:1000669317571

Ren, C., Zhang, W., Zhong, Z., Han, X., Yang, G., Feng, Y., and Ren, G., 2018, Differential responses of soil microbial biomass, diversity, and compositions to altitudinal gradients depend on plant and soil characteristics: Science of the Total Environment, v. 610-611, p. 750-758. https://doi.org/10.1016/j.scitotenv.2017.08.110

Schutter, M., and Dick, R., 2001, Shifts in substrate utilization potential and structure of soil microbial communities in response to carbon substrates: Soil Biology \& Biochemistry, v. 33, p. 1481-1491. https://doi.org/10.1016/s0038-0717(01)00057-8

Tang, J., Tang, X., Qin, Y., He, Q., Yi, Y., and Ji, Z., 2019, Karst rocky desertification progress: soil calcium as a possible driving force: Science of the Total Environment, v. 649, p. 1250-1259. https://doi.org/10.1016/j.scitotenv.2018.08.242

Tian, Y., Wang, S., Bai, X., Luo, G., and Xu, Y., 2016, Trade-offs among ecosystem services in a typical karst watershed, SW China: Science of the Total Environment, v. 566-567, p. 1297-1308. https://doi.org/10.1016/j.scitotenv.2016.05.190

Wakelin, S.A., Macdonald, L.M., Rogers, S.L., Gregg, A.L., Bolger, T.P., and Baldock, J.A., 2008, Habitat selective factors influencing the structural composition and functional capacity of microbial communities in agricultural soils: Soil Biology and Biochemistry, v. 40, no. 3, p. 803-813. https://doi.org/10.1016/j.soilbio.2007.10.015 
Wang, S.J., 2002, Concept deduction and its connotation of karst rocky desertification: Carsologica Sinica, v. 21, p. 101-105.

Wang, Z.J., Li, S.L., Yue, F.J., Qin, C.Q., Buckerfield, S., and Zeng, J., 2020, Rainfall driven nitrate transport in agricultural karst surface river system: Insight from high-resolution hydrochemistry and nitrate isotopes: Agriculture, Ecosystems \& Environment, v. 291, 106787. https://doi. org/10.1016/j.agee.2019.106787

Wei, Y., Yu, L.F., Zhang, J.C., Yu, Y.C., and Deangelis, D.L., 2011, Relationship between vegetation restoration and soil microbial characteristics in degraded karst regions: a Case Study: Pedosphere, v. 21, no. 1, p. 132-138. https://doi.org/10.1016/s1002-0160(10)60088-4

Wu, Q.S., Long, J., Li, J., Liao, H.K., Liu, L.F., Wu, J.N., and Xiao, X., 2019, Effects of different microhabitat types on soil microbial community composition in the Maolan Karst Forest in Southwest China: Acta Ecologica Sinica, v. 39, p. 1009-1018. https://doi.org/10.5846/ stxb201801110084

Yan, Y.J, Dai, Q.H, Hu, G., Jiao, Q., Mei, L.N, and Fu, W.B, 2020, Effects of vegetation type on the microbial characteristics of the fissure soilplant systems in karst rocky desertification regions of SW China: Science of the Total Environment, v. 712, p. 136543. https://doi.org/10.1016/j. scitotenv.2020.136543

Yang, F., Wu, J., Zhang, D., Chen, Q., Zhang, Q., and Cheng, X., 2018, Soil bacterial community composition and diversity in relation to edaphic properties and plant traits in grasslands of southern China: Applied Soil Ecology, v. 128, p. 43-53. https://doi.org/10.1016/j.apsoil.2018.04.001

Zeng, F., Jiang, Z., Shen, L., Chen, W., Yang, Q., and Zhang, C., 2018, Assessment of multiple and interacting modes of soil loss in the Karst Critical Zone, southwest China (SWC): Geomorphology, v. 322, p. 97-106. https://doi.org/10.1016/j.geomorph.2018.08.043

Zhan, W., Liu, S.J., Ye, Y.Y., Chen, H.S., Wang, K.L., and Wang, G.F., 2013, Spatial variability of soil nutrients and its influencing factors in typical karst virgin forest: Transactions of the Chinese Society of Agricultural Engineering, v. 29, p. 93-101. https://doi.org/10.3969/j.issn.10026819.2013.01.013

Zhang, W., Chen, H.S., Wang, K.L., Zhang, J.G., and Hou, Y., 2008, Spatial variability of soil nutrients on hillslope in typical karst peak-cluster depression areas: Transactions of the Chinese Society of Agricultural Engineering, v. 24, p. 67-73.

Zhang, W., Zhao, J., Pan, F., Li, D., Chen, H., and Wang, K., 2015, Changes in nitrogen and phosphorus limitation during secondary succession in a karst region in southwest China: Plant and Soil, v. 391, no. 1-2, p. 77-91. https://doi.org/10.1007/s11104-015-2406-8

Zhao, L., Gai, S.S., Zheng, S.M., Hu, Y.J., Liu, H.Y., and He, X.Y., 2019, Effects of season and microhabitat on soil arbuscular mycorrhizal fungi communities in a karst shrubland: Research of Agricultural Modernization, v. 40, p. 870-877. https://doi.org/10.13872/j.1000-0275.2019.0083

Zheng, J., Liang, R., Zhang, L., Wu, C., Zhou, R., and Liao, X., 2013, Characterization of microbial communities in strong aromatic liquor fermentation pit muds of different ages assessed by combined DGGE and PLFA analyses: Food Research International, v. 54, no. 1, p. 660-666. https://doi.org/10.1016/j.foodres.2013.07.058

Zhou, J., and Lei, T., 2007, Review and prospects on methodology and affecting factors of soil microbial diversity: Biodiversity Science, v. 15, p. 306-311. https://doi.org/10.1360/biodiv.070069

Zhou, L., Wang, X., Wang, Z., Zhang, X., Chen, C., and Liu, H., 2020, The challenge of soil loss control and vegetation restoration in the karst area of southwestern China: International Soil and Water Conservation Research, v. 8, no. 1, p. 26-34. https://doi.org/10.1016/j. iswcr.2019.12.001.

Zhou Zhengxian , 1987, Scientific Survey of the Maolan Karst Forest, Guizhou Renmin Chubanshe, Guiyang: Guizhou People's Press, (in Chinese)

Zhu, H., He, X., Wang, K., Su, Y., and Wu, J., 2012, Interactions of vegetation succession, soil bio-chemical properties and microbial communities in a karst ecosystem: European Journal of Soil Biology, v. 51, p. 1-7. https://doi.org/10.1016/j.ejsobi.2012.03.003 